Revue d'histoire de l'Amérique française

REVUE D.HISTOIRE DE L'AMÉRIQUE FRANÇAISE

\title{
Ascendance de Louis Riel d'après Tanguay
}

\section{Archange Godbout}

Volume 2, numéro 1, juin 1948

URI : https://id.erudit.org/iderudit/037784ar

DOI : https://doi.org/10.7202/037784ar

Aller au sommaire du numéro

Éditeur(s)

Institut d'histoire de l'Amérique française

ISSN

0035-2357 (imprimé)

1492-1383 (numérique)

Découvrir la revue

Citer ce document

Godbout, A. (1948). Ascendance de Louis Riel d'après Tanguay. Revue d'histoire de l'Amérique française, 2(1), 157-157. https://doi.org/10.7202/037784ar d'utilisation que vous pouvez consulter en ligne.

https://apropos.erudit.org/fr/usagers/politique-dutilisation/ 
terminer cette chronique que par un autre mot du rédacteur en chef du Devoir, M. Omer Héroux, dans son premier Montréal du 14 avril, mot qui exprime notre entrain et nos espoirs:

" La route est belle... *

\section{Lionel Grooux, ptre}

\section{ASCENDANCE DE LOUIS RIEL D'APRES TANGUAY}

I - Reel, Jean-Bte dit Irlande, fils de Jean-Bte et de Louise Lafontaine, de St Pierre, ville de Limerick, Irlande, épouse à l'Ile-Dupas, le 21 janvier 1704, Iouise Cottu, dont Jacques, qui suit.

II - Riel, Jacques, dit l'Irlande, fils du précédent, né vers 1706, épousa à StSulpice (contrat de mariage du 7 mai 1730, greffe de Senet) Elisabeth de Ganne. Habitaient Lavaltrie. Ils eurent Jean-Bte, qui suit.

III --.-Riel, Jean-Bte, baptisé vers 1733, épousa à Lavaltrie, 25 janvier 1755, MarieCharlotte Sylvestre. Domiciliés à Lavaltrie, ils furent parents du suivant

IV - Riel, Jean-Bte, baptisé à Lavaltrie, le 3 septembre 1757, épousa Marie Collin, dont Jean-Bte, qui suit.

V-Riel, Jean-Bte, fils du précédent, épousa une métisse française, [une métisse franco-montagnaise, d'après le Père A.-G. Morice, Histoire de l'Église catholique dans l'Ouest Canadien... I, p. 326] et eut:

VI - Riel, Louis, baptisé en 1817, à l'Ile à la Crosse, épousa Julie Lagimodière [Lecompte de la Vimandière.] [Ce dernier fut le père du héros Louis Riel, né à St-Boniface, le 2 octobre 1844].

N.B. Louis Riel avait donc $25 \%$ de sang indien, $3 \%$ de sang irlandais et le reste de sang français.

ce 18 mai 1948 .

P. Archange GodBour, o.f.M. 